\title{
Which Type of Underlying Disease Facilitates Cytomegalovirus Infection? Comparison of Benign Disease, Hematopoietic Malignancy, and Post-bone-marrow or Renal Transplantation Status by Using the First Standardized Objective PCR Test for Cytomegalovirus Detection.
}

\author{
Motofumi HIYOSHI, Shinichi TAGAWA, Shigemi HASHIMOTO and Noriyuki TATSUMI \\ Department of Laboratory Medicine, Osaka City University Medical School, Osaka, Japan.
}

(Received : September 4, 1998)

(Accepted : Nobember 12, 1998)

Key words : cytomegalovirus, PCR, bone marrow transplantation, immunocompromised host

\begin{abstract}
All immunocompromised hosts, such as infants, the elderly, patients with advanced cancer, and patients being treated with immunosuppressants, etc., are said to be more susceptible to cytomegalovirus (CMV) infection or CMV disease. However, we quentioned the validity of this conclusion and attempted to detect CMV viremia in the plasma of subjects by using the AMPLICOR ${ }^{\mathrm{TM}} \mathrm{CMV}$ test (Roche Diagnostics Systems, Branchburg, NJ), the first standardized PCR kit for CMV infection. One hundred healthy volunteers whose CMV IgG titer was $<4$ and 100 healthy volunteers whose IgG titer for CMV was $\geqq 4$ were studied. None of the subjects in either helthy group was positive for CMV viremia. Patients who were suspected of CMV infection were divided into four groups and tested : [1] 104 patients with benign disease, only one of whom was positive for CMV [2] 99 patients with hematopoietic malignancy who had not undergone bone marrow transplantation and all of whom were negative for CMV infection [3] 120 post-bone-marrow transplantation, 28 of whom were CMV positive, [4] 37 post-renal transplantation patients, 19 of whom were CMV positive. A statistically significant difference in CMV positivity was found by the non-parametric Kruskal-Wallis test $(\mathrm{p}<0.0001)$ among the four disease group. CMV infection has been said to occur in all types of immunocompromised patients, however, based on our findings, we conclude that CMV infection tends to occur in post-transplantation status and does not tend to occur in patients with hematopoietic malignancy if they have not undergone transplantation.
\end{abstract}

\section{Introduction}

Since organ transplantation medicine has developed and succeeded recently, CMV infection is now being taken seriounly as a complication of post-transplantation status ${ }^{1 \prime}$.

The problem is that it has been difficult to diagnose CMV infection accurately and immediately, with the result that treatment for possible CMV infection or CMV disease has been started even when laboratory tests for CMV have not been positive. Conventional laboratory tests for CMV infection consist of direct culture methods, serologic methods, and antigenemia assay using monoclonal antibody, but none has

Correspondence to : Motofumi Hiyoshi, MD

Department of Laboratory Medicine Osaka City University Medical School 1-4-3, Asahimachi, Abeno, Osaka, 545-8585, Japan 
been satisfactory in terms of sensitivity, specificity, and time reguired until the results are available ${ }^{2)-5)}$.

The polymerase chain reaction (PCR) is a very promising technique for hospital laboratory work and is now being utilized to diagnose CMV infection ${ }^{1 / 6)-10}$. Thus, at last a standardized objective laboratory test for CMV infection by PCR has become available in clinical medicine ${ }^{11}$. The performance of the test is satisfactory, and its sensitivity and specificity are reported to be $97.1 \%$ and $100 \%$, respectively ${ }^{11}$.

It has been said that all types of immunocompromised hosts, such as infants, the elderly, patients with advanced cancer, and patients undergoing treatment with immunosuppressants, etc., are susceptible to CMV infection or CMV disease ${ }^{1)}$. We wondered if this was true, but no standardized objective method was available to investigate this question properly. When we were given an opportunity to use the above-mentioned PCR laboratory test, the first standardized objective test for CMV infection, we used it to identify the conditions that facilitate CMV infection in the immunocompromised patients.

\section{Materials and Methods}

Study population and sample collection

All specimens were collected after obtaining informed consent. As controls, plasma specimens (EDTA) were collected from 100 healthy volunteers, age $34.1 \pm 5.1$ years (average (mean \pm standard deviation) ) who was CMV IgG titer negative $(<4)$ and 100 healthy volunteers, age $33.7 \pm 6.7$ years, whose IgG titer for CMV was positive $(\geqq 4)$. All of these volunteers had negative for IgM titers for CMV $(<4)$. The serologic CMV antibody studies (both IgG and IgM) were performed by a standard complement fixation method. Of course, the healthy volunteers did not exhibit any symptoms of infectious disease. To compare the four different conditions, plasma specimens were taken from patient cohen they developed an unexplained fever that persisted for over 7 days and did not respond to antibacterial antibiotic or antifungal antibiotic therapy ; i.e.,when the patients were suspected of having CMV infection or CMV disease. There were four categories of patients : [1] 104 patients with benign conditions (50, diabetes mellitus ; 30, post-cardiovascular surgery ; 23, collagen vascular disease ; 1 , diagnosis not made, but at least, no malignant tumors were detected) , [2] 99 patients with hematopoietic malignancy (40, acute leukemia ; 35 , malignant lymphoma ; 10, chronic myelogenous leukemia in blastic crisis ; and 14, myelodysplastic syndrome) , [3] 120 patients who had undergone bone marrow transplantation (80, acute leukemia in complete remission ; 40, chronic myelogenous leukemia in chronic phase), [4] and 37 patients who underwent renal transplantation for chronic glomerulonephritis. Specimens were collected within 120 days of bone marrow or renal transplatation. All specimens from healthy volunteers and patients were stored at $-80^{\circ} \mathrm{C}$ for future CMV detection. All healthy volunteers and patients tested negative for human immunodeficiency virus (HIV).

\section{Polymerase chain reaction for cytomegalovirus}

The polymerase chain reaction was performed by using the AMPLICOR ${ }^{\mathrm{TM}} \mathrm{CMV}$ test (Roche Diagnostics Systems, Branchburg, NJ) according to the manufacturer's instructions. This test was designed to defect CMV viral DNA in plasma (CMV viremia). Briefly, $50 \mu$ l of plasma was mixed with $500 \mu$ l of extraction reagent and were incubated at $100^{\circ} \mathrm{C}$ for $30 \mathrm{~min}$, and $50 \mu \mathrm{l}$ of the mixture was transferred into a PCR tube containing all the components necessary for PCR amplification plus an internal control (IC). The PCR tube was placed in the GeneAmp System 9600 (Perkin-Elmer) for PCR amplification. After amplification, the amplified nucleotide sequences were detected by an enzyme immunoassay technique. Absorbances were measured at $450 \mathrm{~nm}$. Specimens having an absorbance value of $\geqq 0.25$ were considered positive, and values $<0.25$ were considered negative. 
Fig. 1 CMV infection was investigated by attempting to detect CMV viremia with the AMPLCOR ${ }^{\mathrm{TM}}$ CMV PCR test in 100 healthy volunteers whose IgG titer for CMV was $<4$ and 100 healthy volunteers whose IgG titer for CMV was $\geqq 4$. The absorbances were measured at $450 \mathrm{~nm}$. Positive, $\geqq 0.25$; negative, $<0.25$.



Fig. 2 CMV infection was studied by detecting CMV viremia using the AMPLICOR $^{\mathrm{TM}}$ CMV PCR test. Patients who were suspected of CMV infection were divided into four groups : [1] 104 patients with benign disease, [2] 99 patients with hematopoietic malignancy who had not undergone bone marrow transplantation, [3] 120 post-bone-marrow transplantation status patients and, [4] 37 post-renal transplantation status patients. A statistically significant difference was found among the four groups $(\mathrm{p}<0.0001)$. The absorbances were measured at $450 \mathrm{~nm}$. Positive, $\geqq$ 0.25 ; negative, $<0.25$.

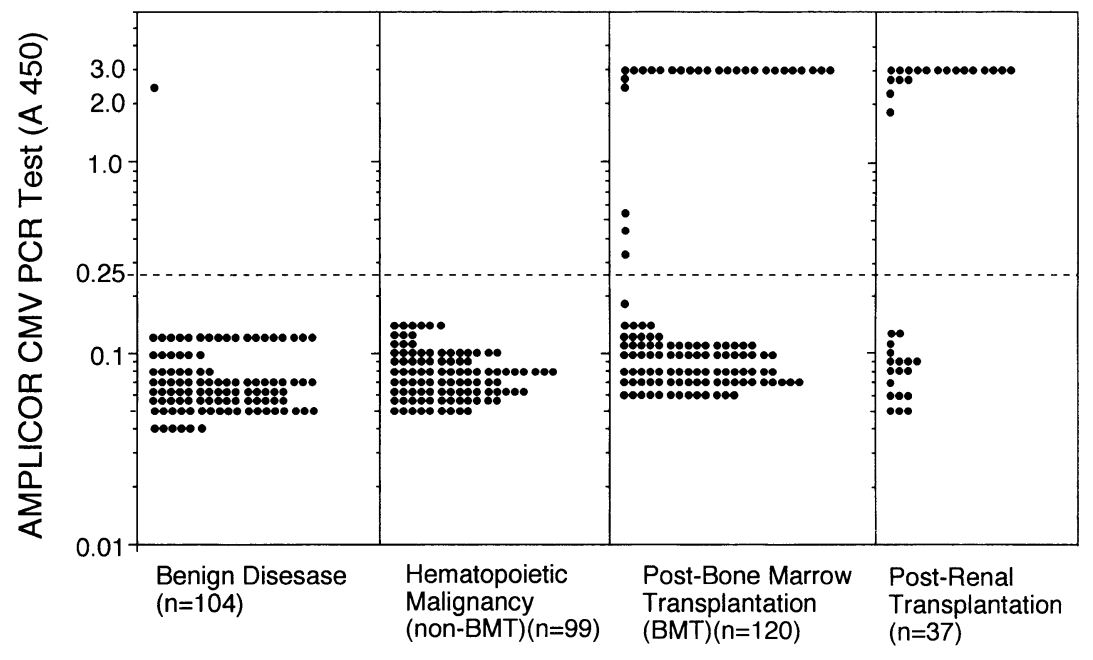

\section{Results}

Cytomegalovirus detection in the plasma of healthy volunteers 
It has been assumed that if CMV DNA is detected in a patient's plasma, the patient can be diagnosed as having CMV infection. In other words, CMV is never detected in the plasma of a healthy person. Although this would seems to be true, no evidence has ever been published to corroborate it. We therefore tried to confirm the validity of this conclusion by using the AMPLICOR ${ }^{\mathrm{TM}} \mathrm{CMV}$ test. We investigated whether it would be possible to detect CMV in the plasma of healthy volunteers. Two different subject groups were established : [1] healthy volunteers who had never been infected by CMV (IgG titer for $\mathrm{CMV}<4$ ) and [2] healthy volunteers who had been already infected by CMV (IgG titer for CMV $\geqq 4$ ) (Fig. 1). Neither of the two groups included any persons who exhibited CMV viremia in their plasma (Fig, 1). These findings suggest that CMV cannot be detected in the plasma of healthy humans. Thus, if CMV DNA in detected in a patient's plasma, the patient can be diagnosed as having CMV infection.

Cytomegalovirus detection in the plasma of immunocompromised patients

We attempted to identify the underlying conditions that facilitate CMV infection (Fig. 2). Only one patient in the benign disease category had CMV vimemia ; but all of the others were negative for CMV infection. None of the patients in the hematopoietic malignancy category had CMV infection ; the patients in this group had never undergone bone marrow transplantation. Twenty-eight patients in the post-bone-marrow transplantation category were positive for CMV viremia, and 19 patients were positive in the post-renal transplantation category. The non-parametric Kruskal-Wallis test was applied to these results (Fig. 2), and a statistically significant difference in positivity for CMV viremia was found among these four categories $(\mathrm{p}<0.0001)$. Basea on these findings, we conclude that $\mathrm{CMV}$ infection tends to occur in post-transplantation status and that it dose not tend to occur in patients with hematopoietic malignancy if they have not undergone transplantation.

\section{Discussion}

Why dose CMV infection tend to occur only in post-transplantation status? An immunosuppressant or a glucocorticoid therapy inhibits a patient's immune system and facilitates proliferation of CMV in the immunocompromised patients of post-transplantation status. However, many patients in the benign disease category such as patients with collagen-vascular disease received such treatment, but did not show any evidence of CMV infection (Fig. 2).

Bone marrow transplantation, patients undergo whole-body irradiation, which completely destroys the patient's immune system including the T-cell system. Although patients with human immunodeficiency virus/acquired immunodeficiency syndrome (HIV/AIDS) were not evaluated in this study, they are known to be susceptible to CMV viremia when their CD 4 count falls below than $50 / \mu{ }^{12)}$, and thus a weakened host T-cell immune system might be associated with CMV infection.

One patient in the benign disease category was positive for CMV infection. The patient's attending physician was unable to diagnose the underlying disease, but, at least, the patient did not have HIV/AIDS or malignant tumor.

According to our results, CMV infection seldom occurs in patients with benign disease or hematopoietic malignancy, even when their condition appears to be serious. Although this must be confirmed in a larger scale study in the future, this finding may be helpful to all physicians caring for patients suspected of having CMV infection or CMV disease.

\section{References}

1) Zipeto D, Morris S. Hong C et al. : Human cytomegalovirus (CMV) DNA in plasma reflects quantity of CMV DNA present in leukocytes. J Clin Microbiol $1995 ; 33: 2607-2611$.

2) Goulan J, Laporte JP, Lesage S et al. : Monitoring of cytomegalovirus infection and disease in bone marrow recipients by 
reverse transcription-PCR and comparison with PCR and blood and urine cultures. J Clin Microbiol $1996 ; 34: 2085^{-}$ 2088.

3) Meyers JD, Ljungman P, Fisher LD : Cytomegalovirus excretion as a predictor of cytomegalovirus disease after marrow transplantation: importance of cytomegalovirus viremia. J Infect Dis $1990 ; 162: 373-380$.

4) Schmidt CA, Oettle H, Wilborn F et al. : Demonstration of cytomegalovirus after bone marrow transplantation by polymerase chain reaction, virus culture and antgen detection in buffy coat leukocytes. Bone Marrow Transplant 1994 ; $13: 71-75$.

5) Boeckh M, Bowden RA, Goodrich JM, Pettinger M, Meyers JD : Cytomegalovirus antigen detection in peripheral blood leukocytes after allogenic marrow transplantation. Blood $1992 ; 80: 1358-1363$.

6) Freymuth F, Gennetay E, Petitjean J et al . : Comparison of nested PCR for detection of DNA in plasma with pp 65 leukocytic antigenemia procedure for diagnosis of human cytomegalovirus infection. J Clin Microbiol $1994 ; 32: 1614-1618$.

7) Ishigaki S, Takeda M, Kura T et al. : Cytomegalovirus DNA in the sera of patients with cytomegalovirus pnemonia. Br J Haematol $1991 ; 79$ : 198-204.

8) Spector SA, Memmill R, Wolf D, Dankner WM : Detection of human cytomegalovirus in plasma of AIDS patients during acute visceral disease by DNA amplification. J Clin Microbiol $1992 ; 30: 2359-2365$.

9) Brytting M, Xu W, Wahren B, Sundwvist V-A : Cytomegalovirus DNA detection in sera from patients with active cytomegalovirus infections. J Clin Microbiol $1992 ; 30: 1937-1941$.

10) Patel R, Smith TF, Espy M et al. : Detection of cytomegalovirus DNA in sera of liver transplant recipients. J Clin Microbiol $1994 ; 32: 1431-1434$.

11) Hiyoshi M, Tagawa S, Takubo T et al : Evaluation of the AMPLICOR CMV test for direct detection of Cytomegalovirus in plasma specimens. J Clin Microbiol $1996 ; 35: 2692^{-2} 2694$.

12) Gozlan J, Salord J-M, Petid J-C : Cytomegalovirus (CMV) late mRNA detection in peripheral blood of AIDS patients with CMV visceral diseases. In : Michelson S, Plotkin SA, eds. Multidisciplinary approach to understanding cytomegalovirus disease. Elsevier, Amsterdam, 1993 ; 329-224.

\section{どんな基礎疾患がサイトメガロウイルス感染を引き起こしやすいか？} 初めての標準化された客観的サイトメガロウイルス用 PCR キットを使用した， 良性疾患, 血液覀性腫瘍, 骨髄悪性腫瘍, 骨髄移植後, 腎移植後における比較

大阪市立大学医学部臨床検査医学教室

日吉 基文田川 進一橋本 卯巴巽典之

\section{要旨}

幼览，老人，癌患者，免疫抑制剂を投与されて いる患者など，あらゆる種類の日和見感染宿主は 活動性サイトメガロウイルス $(\mathrm{CMV})$ 感染など CMV 感染症に容易に罹患する傾向があると言わ れている．我々はこのことが真実であるかどうか 疑問を持ち，世界初の標準化された CMV 感染症 診断用の $\mathrm{PCR}$ キットであるアンプリコア CMV テスト (Roche Diagnostics Systems, Branchburg, $\mathrm{NJ}$ ）を使って対象人の血漿中の CMV ウイルス血 症を検出することにより，この事柄を調べた。 CMVIgG 抗体価 4 未満の健常人 100 人と CMV$\operatorname{IgG}$ 抗体価 4 以上の健常人 100 人が調べられた。 両方の健常人グループには CMV ウイルス血症陽 性は見つけられなかった。また CMV 感染が疑わ れる患者は 4 つのグループに分けて調べられた。

（1） 104 人の良性疾患の患者群は 1 人の $\mathrm{CMV}$ ウ
イルス血症陽性を含んでいた。しかし他の患者は すべて陰性であった. (2) 骨髄移植を受けたことの ない 99 人の血液悪性腫瘍はすべて CMV ウイル ス血症陰性だった.(3) 骨髄移植後の 120 人の患者 群は 28 人の CMVウイルス血症陽性を含んでい た.（4）腎移植後の 37 人の患者群は 19 人の CMV ウイルス血症陽性を含んでいた。これら 4 つの疾 患グループ間で CMVウイルス陽性率の統計学的 有為差がノンパラメトリックテストの一つである クルスカル・ワリステストによって見出された $(\mathrm{p}<0.0001)$. 今日まで, CMV 感染はあらゆる夕イ プの日和見患者に起こると言われてきた。しかし ながら，実は CMV 感染は臓器移植後の状態に陥 りやすい傾向があり，移植を受けていない血液悪 性腫瘍患者には起こりにくい傾向があるというこ とを我々はこれらのデータにもとづき結論する。 